\title{
Democracy and the Islamic State: Muslim Arguments for Political Change in Indonesia
}

\author{
LUTHFI ASSYAUKANIE
}

\begin{abstract}
The main argument of this article is that there has been a significant development in Muslim acceptance of democracy in Indonesia. By comparing two generations of Muslim intellectuals, this paper shows the congruence between the decline of the Islamic political agenda with the rise of a new Muslim generation often dubbed as liberal Muslims. I argue that there is a significant role played by this new Muslim generation in advocating and promoting the idea and practice of democracy. By developing Islamic arguments in dealing with the modern political concepts mostly imported from the West, they are able to vindicate the compatibility of Islam and liberal democracy.
\end{abstract}

\section{The Growing Support of Democracy}

Since the fall of Soeharto, Indonesia has conducted two parliamentary elections which have been considered by many observers to be the most successful and the most democratic elections since 1955. These two general elections reveal a promise that Indonesia will become strongly a democratic state. Jimmy Carter, a former US president who observed the 2004 general election, was very much impressed by the success of the event (International Herald Tribune, 15 July 2004). Likewise, the weekly magazine, The Economist, pointed out the same general election as a 'shining example of Muslim democracy' (The Economist, 10 July 2004). The success of the 2004 presidential election is not only because it was held peacefully, in spite of the devastating bombing in the Australian embassy eleven days earlier, but also because it was held fairly and democratically.

As a matter of fact, the last two general elections in Indonesia do not only reveal a prognosis of democracy, but also evince the surprising fact about the development of Islam in Indonesia. Judging from the result of the two general elections, Indonesian Muslims, we might say, are politically becoming more moderate and more rational. That is to say: they are no longer obsessed with Islamic ideology which previously predominated in their minds. In the 1950s, Muslims who supported 
Islamic ideology were almost half of the population. This was revealed in the 1955 general election where about 43 percent of them voted for Islamic parties. Islamic parties are those parties that espoused Islamic ideology (identified by endorsing the Islamic state and the application of Islamic law or shariah) as their political garb. However, since the last two general elections, this condition has changed dramatically as all Islamic political parties obtained no more than 17 percent of the total votes. ${ }^{1}$

Certainly, supporting Islamic political parties or endorsing the idea of Islamic state does not necessarily mean that Muslims during the 1950s were against democracy. As a matter of fact, many of them, particularly the modernists, ${ }^{2}$ claimed to have worked and struggled for democratic life in the country. Only that the democracy they favoured was that kind of what David Collier and Steven Levitsky call 'democracy with adjectives' (Collier and Levitsky 1997). Committed to and strongly inspired by Islamic ideology, those Muslims established what they call 'Islamic democracy' or 'theo-democracy', which ended up excessively concerned with Islamic interests. Like many other kinds of democracy with adjectives, Islamic democracy seriously ran into trouble, particularly with regard to the issue of pluralism and minority rights in the country.

The 1999 and 2004 general election have disclosed that Indonesian Muslims are no longer concerned with the aliran politics or ideological stream. In fact, they now find it more convenient to express their political aspirations in various political parties. In the past, political domain in the country was sharply determined by what is called 'aliran.' The santri Muslims, that is Muslims with a religious background, were unlikely to affiliate to secular parties as they were branded as secularist political vehicles. Secular parties were mostly supported by abangan or those Muslims who embraced Islam nominally. As the platform of political parties was strongly ideological, the affiliation of its members was thus strongly driven by the aliran groups.

Apart from that, in the last two decades, Indonesian Muslims have enthusiastically been involved in various democratic activities. Islamic organizations such as Muhammadiyah and Nahdlatul Ulama (NU) have actively been supporting the empowerment of civil society and the process of democratisation in the country. Even more importantly, Muslim leaders from both organizations have been enthusiastically engaged in the intellectual and political discourse to effectuate a more moderate and more liberal Islam. Hence, not only were they were against the idea of Islamic state or the implementation of Islamic laws, but also endorsing a more moderate and 'secular' platform of the state. 
The question is, naturally, why all these happen in such a biggest Muslim country? Why Indonesian Muslims, despite several 'Islamic' terrorisms that bashed the country quite recently, are generally more moderate and tend to abandon their old ideology? This article is mainly designed to answer this kind of questions.

\section{The Emergence of New Muslim Generation}

Many writers and observes hold a view that the decline of Islamic political parties in the last two general elections in Indonesia is greatly due to the Soeharto's policy towards Islam. Since he ruled the country, Soeharto was extremely anxious about the ideological divergences inherited from the former regime. He saw that ideological conflicts were not conducive for the national integration as well as for the economic betterment of the country. Thus, during the first decades of his rule, he set an agenda of unification and development. Initially, he banned the communist party (and communism in general), disallowed Masyumi, the old and the biggest Islamic political party which was banished by Soekarno, to be rehabilitated, and fusing all political parties into merely two parties. He himself supported Golkar, a quasi-political party, founded by the military.

Soeharto was a Javanese abangan, who had little interest in religion. Many Muslims even saw him to be hostile towards Islam. During the first decades of his rule, he forbade any Islamic political parties, denigrated Muslims as extremists, and forced them to accept the sole basis of Pancasila, an act that was regarded by many Muslims as an intrusion into their Islamic creed. However, not all santri Muslims were against him. Already in the early 1970s, there grew a new generation of santri Muslims who were arguably more favourably disposed to work with Soeharto's agenda of development than to follow suit the old path of their elders. However, it must not necessarily be understood that they had simply been coopted by Soeharto. As a matter of fact, many of them were independent intellectuals and were critical of the regime.

Those intellectuals, variably known as 'new Muslim generation' (Effendy 2003), 'Muslim renewalists' (Hassan 1980), 'Muslim neo-modernists' (Barton 1995, 1997), and 'liberal Muslims' (Qodir 2003), have made a radical shift from the old Islamic political paradigm. Mostly educated in religious and secular institutions, they are proficient in both Islamic and Western knowledge. Unlike their elders, this new Muslim generation 'was less concerned about old issues, about the schism between Orthodoxy and Modernism, or about the difficulties of living within an increasingly 
multireligious society' (Ricklefs 2001: 343-44). As far as the delegitimation of Islamic ideology is concerned, their role is no less significant than Soeharto. In fact, to a great extent, they are more cogent than any other factors. Genealogically, the new Muslim generation comes from a santri background and many of them are descendants or relatives of Masyumi and Nahdlatul Ulama (NU).

Some of them were active during the early period of Soeharto's rule, and some other emerged during the 1980s. Mohammad Sjafaat Mintaredja (b. 1921) and Abdul Mukti Ali (1923-2004) were examples as of those who were active during the early period of Soeharto's rule. Both served as Ministers in the first Soeharto cabinet, as Minister of Social Affairs and Minister of Religious Affairs respectively. However, among the early Muslim reformists, Nurcholish Madjid is perhaps the most articulate and daring intellectual in delegitimizing the old Islamic ideology.

Born into a strong santri family, Madjid was confident to speak about Islamic reformism. In 1970, he wrote and delivered a paper entitled 'The Necessity of Renewing Islamic Thought and the Problem of the Integration of the Ummah' (Madjid 1970). This paper took the country by storm and caused an enduring controversy within the history of Islamic political discourse in Indonesia. Madjid's role is indeed important since he had laid a theological foundation for the unstoppable Islamic reformism. One of the most provoking thoughts he introduced in the article was his appeal for Muslims to refuse the Islamic politics which had dominated Muslim political thought during the last two periods. His slogan 'Islam Yes, Islamic Party No' had soon become the brand of all his reformist thoughts. Although Madjid's ideas were initially attacked from every corner, his essential message that Indonesian Muslims must differentiate between religion and politics (this was the soft version of 'the separation between religion and the state') was widely received.

The wave of the delegitimation of Islamic ideology reached its culmination in the mid 1980s, when many from a new Muslim generation came on to the political stage. It was a coincidence that during this time a number from the new Muslim generation had just graduated from their study abroad. Madjid himself had just attained his Ph.D. from Chicago University. Muhammad Amien Rais and Ahmad Syafii Maarif, two towering leaders who then became the chairmen of Muhammadiyah successively, also graduated during this time, from the same university with Madjid. A growing number of Muslim intellectuals played their significant role during this time too. Intellectuals such as M. Dawam Rahardjo, Kuntowidjoyo, Jalaluddin Rakhmat, Munawir Sjadzali, and Abdurrahman 
Wahid (the future President), lived out their productive years in writing and developing Islamic thought during this particular time.

We will see how do they play their role, particularly in developing Islamic argument vis-à-vis political changes in Indonesia. And how different they are from the old generation of santri Muslims in dealing with political issues?

\section{Muslim Earlier Standpoint vis-à-vis Democracy}

As I have said, the older generation of Indonesian Muslims were not against democracy. In fact, most of them wanted their country to be a democratic state. However, their understanding of democracy was fundamentally limited by the values of the classical Islamic political doctrines they subscribed to. For the older generation, democracy was not incompatible with the idea of an Islamic state. In fact they believed the Islamic state in its original form to be democratic. Thus, based on this understanding, they developed a new concept of what is called 'Islamic democratic state' or what Muhammad Natsir-one of the proponents of this concept-called 'theo-democracy. ${ }^{13}$

The Muslim understanding of democracy was at first, procedural (often called 'electoral democracy'). That is, democracy was understood to be a viable mechanism to elect the political leader, to control the leader (through parliament), and to invite people's participation (by involving them in the democratic institutions). They believed that as a procedural concept, democracy is compatible with Islam, since Islam, they argued, has a similar concept (such as shura). Zainal Abidin Ahmad, a prolific author of this generation, argued that Islam is a democratic religion and has once experienced democracy in its early history. ${ }^{4}$ Ahmad pointed out the democratic life in the time of the Prophet and his four successors (khulafa al-rashidun). According to him, during this time, Muslims lived out their political life in a democratic way. That is, they had a meeting place which resembled modern day parliaments. They also effected out a political transfer of power that could be equated with the idea of a general election in the modern era (Ahmad 1956: 111).

As a procedural concept, democracy is also compatible with Islamic political doctrines. The Old Muslim generation found that some Qur'anic verses clearly encourage Muslims to hold a process of deliberation or shura (The Qur'an 42:38; 3:159; 2:233). Likewise, classical Islamic political doctrines have a lot of political notions comparably similar to the modern political concepts, such as imamah, ahl hal wa al'aqd, and bay'ah. In addition to this, there are also many Prophetic traditions (hadith) 
indicating the democratic life in the early history of Islam. The succession of the four caliphs was often exaggerated as the ideal type of the democratic implementation in Islam.

Furthermore, the old Muslim generation understood democracy as majority rule. That is to say, democracy allows the majority to rule and govern the country. The majoritarian argument was frequently used by the old Muslim generation to justify their political aims. Arguing that Muslims are the majority in the country, it is thus democratic to allow Muslims to determine the form of the state. This argument has been prevalent since pre-independence. The call for a state founded upon Islamic basis in the BPUPKI meetings, ${ }^{5}$ for example, was based upon this very argument. Likewise, the recurrent demand of the Jakarta Charter (in which shariah must be implemented at state level) was based upon the same argument.

As a matter of fact, the argument of majority rule is actually presumed since it was mainly based on a Muslim assumption. It was entirely grounded on the demographic reality of Indonesian Muslims. Politically, Indonesian Muslims were (and are) not monolithic and they cannot be unified into one political aspiration. Suffice to us to mention the 1955 general election where Islamic fundamental aspirations (represented in Islamic political parties) were supported by less than a half of the population.

The old Muslim generation used to consider democracy as 'people's sovereignty.' And this idea was often contrasted to that of 'God's sovereignty.' They did not use this conflicting subject of sovereignty to reject the concept of democracy, but to limit it. For them, democracy is acceptable as long as it does not harm the laws of God. There are certain things, they argued, that cannot be discussed democratically. Muhammad Natsir explained:

Somebody will perhaps ask this question: Is Islam undemocratic? We answer: Islam is democratic in the sense that it is against dictatorship (istibdad), against absolutism, and against authoritarianism. [Democracy] does not mean the parliament's decision to abrogate [the legal status of] gambling and pornography and as to whether the myths (khurafat), idolatry (kemusyrikan), etc., should be discussed democratically. No! This is not the right of Parliament to discuss. (Natsir 2001: 89)

For the old Muslim generation, democracy cannot be removed from religion. In fact, its existence must be aimed at serving religion. Democracy which is not guided by religion tends to be secular and thus against Islam. They strongly opposed to the idea of political secularisation. 
The old Muslim generation also tend to ignore the substantialist meaning of democracy. This can be seen, for example, from their attitude toward the issue of political equality and the rights of minorities. Equality is one of the fundamental pillars of democracy. Equality in democracy means that all citizens are treated equally and all of them have the same political rights. Basically, most of them were aware of this. They fully understood that equality is one of the cardinal principles of democracy. However, if we take a look at their writings and their political attitudes towards the non-Muslim rights, the discriminative impression cannot easily be ruled out. Natsir was frank in his attitude toward this issue. In one of his essays, he wrote:

I hope people will understand if we say that those who are non-Muslims cannot be appointed as leader, that is as vertrouwens persoon as ulil amri of Muslims in their struggle to establish an Islamic state. If we say so, we do not mean that we are provoking or inflaming, or such as this. We just do this because we follow the teachings of our religion. (Natsir 2001: 56; cf., Natsir 1969: 183-190)

Obviously, the old Muslim generation were heavily influenced by the classical Islamic political doctrines. The classical view on the status of non-Muslims is notoriously discriminatory. Classical books on Islamic political theories since al-Mawardi (972-1058) to Ibn Taymiyyah (1263-1328) clearly distinguish political community between Muslims and non-Muslims (dhimmi). The current attempts to reinterpret these doctrines seem to have failed. Zainal Abidin Ahmad, for instance, criticized the classical distinction of community into dhimmi and non-dhimmi. He reinterpreted the concept of dhimmi into just a mere sociological concept for administrative purposes, which can be compared with the modern political categorization of citizenship. ${ }^{6}$ However, when he dealt with the political leader, he applied the classical distinction. He said that all members of non-Muslim society have equal rights as citizens, including in politics, economic matters, and even in the military (Ahmad 1956: 65). 'Only one position', Ahmad argues, 'that is not allowed to be held by non-Muslims, that is the position of caliph or the head of state' (Ahmad 1956: 64).

Seen from a liberal democratic point of view, such an attitude is problematic. First of all, because democracy needs an independent and objective condition. A political system or a state which is dominated by religion would not run democratically, since religion is subjective. It is even more problematic when a particular religion claims that it is better and more eligible to rule than the religion of other communities. This and other aspects of 'undemocratic' views became the main target of criticism 
launched by the younger Muslim generation. With critical analysis they were able to question the political doctrines advocated by their seniors.

\section{New Arguments for Democracy: Rejection of Islamic State}

The new generation of Muslim intellectuals believe that Islam is completely compatible with democracy. Their relationship to liberal democracy is aptly described in a statement made by Rashid Ghannoushi, the Tunisian Islamist leader: 'If by democracy is meant the liberal model of government prevailing in the West, a system under which the people freely choose their representatives and leaders, in which there is an alternation of power, as well as all freedoms and human rights for the public, then Muslims will find nothing in their religion to oppose democracy, and it is not in their interests to do so' (Esposito and Voll 2001: 114). For the new Muslim generation in Indonesia, liberal democracy is the best model of polity human beings have ever produced. They believe that democracy will enable Muslims to fulfil their religious obligations and to undertake their faith in this modern world. In other words, democracy is not only good for governing the secular human life, but also good for fulfilling the spiritual dimension of life.

Based on such a conviction, the new Muslim generation argue that an Islamic state is no longer relevant for Muslim political life. What they mean by 'Islamic state' is that political model previously supported by the older Muslim generation either under the disguise of the concepts of 'theo-democracy' or 'Islamic democratic state.' They are not interested in this kind of ideas simply because such ideas ultimately harm the true meaning of democracy.

It is important to note here that the concept of Islamic state was never openly criticized by the older generation of santri Muslims. Even the 'liberal' intellectuals like Sjafruddin Prawiranegara ${ }^{7}$ or Mohammad Roem ${ }^{8}$ were cautious as to how to criticize this concept. Roem launched his very careful criticism only late in 1980s, in a response to Amien Rais's statement about the issue. As I have said elsewhere, during the 1950s criticism of an Islamic state mostly came from the abangan Muslims who were affiliated to non-Islamic parties. Before 1970, it was simply unimaginable to see an Islamic leader criticizing this concept, since it would damage his or her credentials. Besides that, almost all santri Muslims were affiliated to Islamic political parties whose ultimate target was to establish an Islamic state (or more accurately a state based on Islam).

The rejection of the concept of Islamic state began in the early period of the New Order. One of the earliest Muslim critics of the concept was Mu- 
hammad Sjafaat Mintaredja. ${ }^{9}$ Mintaredja argues that Indonesian Muslims were not likely to establish an Islamic state, not only because Indonesia is a pluralist country in which its constitution does not allow them to do so, but also because the idea of an Islamic state is theologically untenable. The Qur'an and the Hadith, the two most authoritative sources of Islam, according to him, do not have the doctrine of an Islamic state and the Qur'an does not request Muslims to specifically establish a particular model of polity (Mintaredja 1976: 85). Mintaredja deplores the political strategy of Masyumi which so much emphasizes the ideological aspect while ignoring the more important aspects directly felt by Muslims, such as economic and welfare problems (Mintaredja 1976: 62). The economic issue, according to him, is not less essential than the ideological one.

Mintaredja's criticism of the Islamic state is part of the Islamic reformist campaign that has been started since the second half of the 1960s. Nurcholish Madjid, although he did not speak specifically about the Islamic state, is well known for his role as the staunch critic of Islamic ideology. His severe criticism of Islamic political parties and his notorious slogan 'Islam Yes Partai Islam No' was an indirect criticism against the predominant discourse of the Islamic state at the time. However, the most conspicuous and forthright critique of the concept of Islamic state has actually only begun during the early 1980s, when more and more Muslim intellectuals launched their criticisms of the concept.

The most creditworthy figure initiating this movement was Amien Rais. ${ }^{10}$ The story began in November 1982, when an Islamic magazine, Panji Masyarakat, published its interview with Rais. Shortly after, the interview was published with a bombastic title 'Islamic State Does Not Exist' (Panji Masyarakat, 1 November 1982), the issue went nationwide. Responses came forcefully from its readers. The rubric 'letters from readers' of the magazine had for weeks been occupied by comments towards the interview, both pro and con. According to Syafii Anwar, the editor of the magazine, the edition which reported the interview was quickly sold out and many people contacted the magazine office to ask for more copies (Anwar 2002). One of the most important responses was the article written by Mohammad Roem, a leader of Masyumi, published in February 1983 (Panji Masyarakat, 11 February 1983). Surprisingly, Roem supported Rais's statement, although he did it quite carefully. This is most probably because Roem did not want to insult his Masyumi friends. ${ }^{11}$

In its turn, Roem's article was unexpectedly responded to by many Muslims, more probably because the article was shocking to them, as 
Roem was known as the eminent leader of Masyumi which during 1950s was part of those who struggled to uphold the idea of Islamic state. One of the most important responses came from Nurcholish Madjid who was then a Ph.D. student at the University of Chicago, the United States. Madjid sent a long personal letter to Roem, expressing his compliments and thanks for writing such an inspiring article. Roem was soon replying to Madjid's letter, and for six months the two intellectuals from different generations established a correspondence discussing current issues of Islam in Indonesia. Several years later, their letters were published and soon became an important source for the Islamic political discourse in contemporary Indonesia (Madjid and Roem 2000).

In the interview, Rais stated that the aim of nation formation was to promote welfare and justice. Islam does not specifically mention how exactly such welfare and justice should be promoted. The Qur'an and Hadith only give guidelines while the details are given freely to human beings. He writes:

Islamic State or negara Islam, I think does not exist in the Qur'an as well as in the Sunnah. Therefore, there is no desideratum in Islam to establish an Islamic state. What is important is as long as a state has maintained Islamic ethics, social justice, and bringing about an egalitarian society which is far from exploitation of man over man or group over group, it is then, according to Islam, considered a good state. (Rais 2000: xxii)

Rais criticizes countries that are using Islam to define themselves but do not exemplify model states. He points out as an example how Saudi Arabia claims to be an Islamic state but reflects a very bad image of Islam. In fact, the monarchist system that it adopts, Rais argues, contradicts the very basis of an Islamic political system (Rais 2000: xxii). Thus, for Rais, an Islamic state does not depend upon the name alone, but rather on how it can comply with justice, equality and prosperity.

Rais's open rejection of the Islamic state was very important for the development of Islamic political discourse in Indonesia. Not only because he is the leader of Muhammadiyah, the second biggest Islamic organization, but also because Rais was often regarded as a Muslim activist of the Masyumi stock. ${ }^{12}$ Rais's breakthrough has paved the way for other Muslim intellectuals and leaders to go in the same direction. Thus, subsequent to him, we see Munawir Sjadzali come on to the stage with the same tone. ${ }^{13}$ Although he was older than most Muslim intellectuals in his generation, Sjadzali became involved in the Islamic intellectual discourse some time later. This was mainly because he was working as state officer in the Department of Foreign Affairs. Only af- 
ter he was appointed as Minister of Religion was he more sensitive in dealing with Islamic issues.

Sjadzali's criticism of the concept of an Islamic state had actually begun in 1950, when he, under the pseudonym Ibnu Amatillah, wrote a brochure on the question of the Islamic basis of the state (Ibnu Amatillah 1950; cf., Assyaukanie 2004). At this time, he was, however, only questioning the concept without explicitly challenging it. His more serious criticism and objection to the concept of an Islamic state was made only in the mid 1980s, when new Muslim intellectuals, promoted by such thinkers as Nurcholish Madjid, Abdurrahman Wahid, Syafii Maarif, and Amien Rais, played their role. Concurrently, Sjadzali was appointed as Minister of Religion. Because of this, he wrote several articles and one book which became his monumental work (Sjadzali 1990). ${ }^{14}$ Like Rais, Sjadzali argues that the Qur'an does not specifically ask Muslims to build a particular form of government. There are many things in this world to which religion does not have an answer. Islamic jurists have divided human issues into what is called mu'amalah (worldly activities) and ibadah (pure devotion). While in ibadah, Muslims are required to stick to the religious doctrines, in $m u^{\prime}$ amalah, they are given flexibility and freed to do what they think to be good. Political matters, Sjadzali argues, are part of mu'amalah (Sjadzali 1990: 204).

Sjadzali criticizes Muslims who over-idealized the history of Islam in that they imagine the early life of Islam, particularly in the time of the Prophet and the first four caliphs, to be an ideal model to which every Muslims should emulate. He severely criticizes the Pakistani thinker, Abu A'la Maududi, for his idealistic exaggeration in depicting the early Muslim political community:

With our respect to Abu al-A'la al-Maududi as a devoted Muslim fighter as well as a productive writer, I have forcedly to say that his views of Islamic political system have many flaws and contradictions. He looks at the history of political life of the guided caliphs (al-khulafa al-rashidun) seems to me as if he was looking at Merapi mountain. He looks at it from a room balcony at the level six of the Ambarukmo Hotel, Yogyakarta. From such a place, Merapi is indeed a beautiful mountain, particularly if we see it in the bright morning. But I am not satisfied to see the Merapi in such a remote place. I have to invite the readers to go closer and closer until to the post of vulcanology observatory. Here, Merapi is not as beautiful as it is seen from Ambarukmo Hotel, as we clearly see the precipitous hill and also the smell of vulcanite. Certainly, we are here not looking for beauty, but for reality. (Sjadzali 1990: 170) 
Sjadzali wants to argue that too much idealization of the early experience of Muslim politics is extremely dangerous, for one thing that politics, wherever and whenever it is, is not free from intrigues and interests. How could we say that the early life of Islamic politics was a good example if we know that conflicts and wars were part of the daily life of the Prophet and the last three caliphs of the 'guided caliphs' were brutally killed? All these things, Sjadzali argues, are only to ascertain us that the early Muslims were no more than 'political animals, as we can find in every stage of history. They were not super human' (Sjadzali 1990: 234).

\section{Conclusion}

The rejection of the concept of Islamic state or the state based on Islam is crucial for the development of democracy in Indonesia. It has truly paved the way for Muslims to be more independent and more rational in dealing with political matters. In the past, santri Muslims were daunted by religious ideology in that it was almost impossible for them to think politically outside a religious framework. Even if they thought about democracy, they understood it within the framework of religious thinking, which at the end only accentuated their religious identity rather than speaking of a real democracy. However, new arguments set by younger generation have eased the burden of Indonesian Muslims confidently to leave their old political paradigm and unhesitatingly to accept the true meaning of democracy.

Luthfi Assyaukanie is a Ph.D. candidate at the University of Melbourne and Research Fellow at Freedom Institute, Jakarta.

\section{NOTES}

1 We are not talking about general elections during the Soeharto era, mainly because they were not fairly conducted, since the military regime had intervened in all political processes in the country. In addition, there was no independent Islamic party during this period of time, particularly after the implementation of the sole basis (asas tunggal) in 1984.

2 'Muslim modernists' usually refers to a group of intellectuals who were educated in modern institutions and were affiliated to the modern organizations. Muhammadiyah and most of the Masyumi leaders were often regarded as modernists, Nahdlatul Ulama (NU) members as traditionalists.

3 Mohammad Natsir (1908-93) was the most important figure of the old Muslim generation. He was not only the one who introduced the term 'Islamic Democratic State', but also the most consistent leader supporting this idea. Natsir was a thinker 
as well as a politician. He had written on political issues since he was a student in Bandung. Formally, he studied in Algemeene Middelbare School (AMS), a Dutch high school, but informally studied Islam with Ahmad Hassan (1887-1962), the charismatic leader of Persatuan Islam (Persis). Although he only graduated from AMS, Natsir was a brilliant autodidact. He mastered six foreign languages: Latin, Dutch, German, French, English, and Arabic. Natsir did not write a book. However, his articles which he wrote since his youth have been collected into several books. The two volume collections, Capita Selecta, are unquestionably his most important work. From 1949 to 1958, Natsir chaired Masyumi and was elected Prime Minister in 1950.

4 Zainal Abidin Ahmad (1911-83) was politically affiliated to Masyumi. He was born in Minangkabau and educated in Padang Pandjang. In 1935, he edited a magazine called Pandji Islam. It was under his editorship that the long familiar debates between Soekarno and Natsir took place. Zainal Abidin was more of an intellectual and academician than a politician. Unlike Natsir, he wrote several books and was deeply involved in several educational institutions. In his later age, he held the position of President of the Institute of Qur'anic Science (PTIQ), a prestigious college of Qur'anic studies in Jakarta. Zainal Abidin was much interested in political philosophy and wrote mostly on political thought. His best work, Membentuk Negara Islam (Building an Islamic State), is a conceptual blueprint of the Islamic model of democratic state.

5 BPUPKI stands for Badan Penyelidik Usaha Persiapan Kemerdekaan Indonesia (committee to prepare for Indonesian Independence). This committee was founded on 1 March 1945 and held its first meeting from 2 May until 1 June.

6 Like the distinction of citizen or non-citizen (warga negara Indonesia, WNI) and foreign citizen (warga negara asing, WNA), or Indonesian citizen by birth (warga negara Indonesia keturunan, WNI Keturunan). These are all for administrative purposes.

7 Sjafruddin Prawiranegara (1911-89) was born in Serang, Banten, from a santri aristocrat family. His father was a Dutch ambtenaar (pangreh praja officer) and was fairly Westernized. Like Natsir, Sjafruddin studied in AMS in Bandung and continued to RHS (Rechts Hoge School), a Dutch school of law, in Jakarta. Although he graduated in Law and was more interested in Literature, Sjafruddin was asked to work in Departement van Financien (Financial Department). After independence, he was appointed Minister of Finance in the Sjahrir's third cabinet (1946). After some other ministerial posts, Sjafruddin was appointed as the first Director of Indonesian Bank. His other important political roles were as the head of the Emergent Government of the Republic of Indonesia (Pemerintahan Darurat RI, PDRI) in 1948 and the head of the Revolutionary Government of the Republic of Indonesia (Pemerintahan Revolusioner RI, PRRI). In spite of his dense political activities, Sjafruddin was a prolific writer. He wrote a number of books and various articles on Islam and economic issues.

8 Mohamad Roem (1908-83) was known as an adept diplomat who made the image of Masyumi rather high profile. He held various positions in several cabinets. He wrote social and political issues in national media, which have now been compiled into four volume books entitled Bunga Rampai dari Sejarah.

9 Mohammad Sjafaat Mintaredja was born in Bogor in 1921 and was educated in Gadjah Mada University, Yogyakarta. He was the founder of the Muslim Student Association (Himpunan Mahasiswa Islam, HMI) and was its first chairman (194750). He was also noted for his role as chairman of Parmusi, an Islamic party created by the New Order government. His criticism of this concept can be found in his writings published in the late 1960s, such as Masjarakat Islam dan Politik di Indonesia; Renungan Pembaharuan Pemikiran (1971) and Islam dan Politik: Islam dan Negara di Indonesia (1976). 
10 Amien Rais was born in Solo in 1944. He obtained his master's degree from the University of Notre Dame and doctor's degree from the University of Chicago, both in political sciences. Since 1998, he has been regarded as the locomotive of reform for his role in pushing Soeharto from power. In the same year, he founded a political party, a vehicle that brought him to the chairman of the People's Consultative Assembly (Majelis Permusyawaratan Rakyat, MPR). In 2004, he joined the race for the presidential chair, but he failed.

11 Most of leading figures of Masyumi were still alive at the time. They include M. Natsir, Hamka, Zainal Abidin Ahmad and Sjafruddin Prawiranegara.

12 In his letter, Madjid admitted that he was somewhat surprised by Amien's statement since the latter had been well known as an Islamic activist whose ideas tended to be conservative rather than liberal.

13 Sjadzali was born in Klaten, Central Java, in 1925. He was educated in Solo and completed his advanced study in Mamba al-'Ulum in the same city. He took his BA from Exeter University in diplomatic studies and obtained his master's degree from Georgetown University in political science. Before serving as a Minister, he served as Ambassador in Kuwait.

14 This book has been translated into English under the title Islam and Governmental System: Teachings, History, and Reflections. Jakarta: INIS, 1991. One of Sjadzali's crucial moves during his service as Minister of Religion was to introduce the idea of what he calls 'reactualization.' What he means by 'reactualization' is an attempt to review and rethink primary Islamic sources, particularly the Qur'an, in order to give a new understanding which is more authentic and more compatible to the spirit of the age. The criticism of the idea of an Islamic state was part of Sjadzali's project of reactualization. See intellectual responses of his idea in his book: Polemik Reaktualisasi Ajaran Islam (1988).

\section{REFERENCES}

Ahmad, Zainal Abidin 1956. Membentuk Negara Islam. Djakarta: Widjaya.

Anwar, M. Syafii, December 2002 (conversation).

Assyaukanie, Luthfi 2004. 'Ibnu Amatillah itu Munawir Sjadzali.' Kompas, 27 August.

Barton, Greg 1995. 'Neo-Modernism: A Vital Synthesis of Traditionalist and Modernist Islamic Thought in Indonesia.' Studia Islamika, 2: 1-75.

-1997. 'Indonesia's Nurcholish Madjid and Abdurrahman Wachid as Intellectual 'Ulama': The Meeting of Islamic Traditionalism and Modernism in Neo-Modernist Thought', Studia Islamika, 4 (1): 29-81.

Collier, David and Steven Levitsky 1997. 'Democracy with Adjectives: Conceptual Innovation in Comparative Research.' World Politics 49(3): 430-51.

Effendy, Bahtiar 2003. Islam and the State in Indonesia. Singapore: Institute of Southeast Asian Studies.

Esposito, John L. and John Obert Voll 2001. Makers of Contemporary Islam. New York: Oxford University Press.

Hassan, Mohammad Kamal 1980. Muslim Intellectual Responses to 'New Order' Modernization in Indonesia. Kuala Lumpur: Dewan Bahasa dan Pustaka Kementerian Pelajaran Malaysia.

Ibnu Amatillah, M. Sj 1950. Mungkinkah Negara Indonesia Bersendikan Islam: Analyse. Tjet. 1. ed. Semarang: Usaha Taruna. 
International Herald Tribune, 15 July 2004.

Madjid, Nurcholish 1970. 'Keharusan Pembaharuan Pemikiran Islam dan Masalah Integrasi Ummat'. In Utomo Danandjaja, Pembaharuan Pemikiran Islam. Jakarta: Islamic Research Centre.

Madjid, Nurcholish and Mohamad Roem 2000. Tidak Ada Negara Islam: Surat-Surat Politik Nurcholish Madjid-Mohamad Roem. Cet. 2., rev. ed, Jakarta: Djambatan.

Mintaredja, Mohammad Sjafaat 1971. Masjarakat Islam dan Politik di Indonesia; Renungan Pembaharuan Pemikiran, 1. ed. Djakarta: Permata.

-1976. Islam dan Politik: Islam dan Negara di Indonesia. 2. ed. Jakarta: Septenarius.

Natsir, Mohammad 1969. Islam dan Kristen di Indonesia. Tjet. 1. Bandung: Penerbit Peladjar.

-2001. Agama dan Negara dalam Perspektif Islam. Cet. 1. ed. Jakarta: Media Da'wah.

Panji Masyarakat, No. 376, 1 November 1982.

Panji Masyarakat, No. 386, 11 February 1983.

Qodir, Zuly 2003. Islam Liberal: Paradigma Baru Wacana dan Aksi Islam Indonesia. Yogyakarta: Pustaka Pelajar.

Rais, M. Amien 2000. 'Tidak Ada Negara Islam'. In Nurcholish Madjid and Mohamad Roem 2000. Tidak Ada Negara Islam: Surat-Surat Politik Nurcholish MadjidMohamad Roem. Cet. 2. rev. ed., Jakarta: Djambatan.

Ricklefs, M. C. 2001. A History of Modern Indonesia since C.1300. 3. ed. Basingstoke: Palgrave.

Sjadzali, Munawir 1988. Polemik Reaktualisasi Ajaran Islam. Cet. 1. ed. Jakarta: Pustaka Panjimas.

-1990. Islam dan Tata Negara: Ajaran, Sejarah, dan Pemikiran. Cet. 1. ed. Jakarta: Penerbit Universitas Indonesia.

The Economist, 10 July 2004. 